\title{
SPINDLE CELL CARCINOMA OF THE TONGUE: A CASE REPORT IN A YOUNG PATIENT
}

\author{
CARCINOMA DE CÉLULAS FUSIFORMES DA LÍNGUA: RELATO DE CASO EM \\ PACIENTE JOVEM
}

\author{
Francisco Assis Almeida LIMA - JÚNIOR ${ }^{1}$; Rafael Barreto Vieira VALOIS ${ }^{1}$; \\ Simone Alves Garcez GUEDES ${ }^{\mathbf{1}}$; Juliana Batista Melo FONTE ${ }^{\mathbf{1}}$; \\ Maria de Fátima Batista MELO² ${ }^{2}$ Ericka Janine Dantas SILVEIRA ${ }^{3}$;
} Silvana Vieira Floresta GOMES ${ }^{4}$; Ricardo Luiz Cavalcanti ALBUQUERQUE - JÚNIOR ${ }^{4}$

1. Universidade Tiradentes - UNIT, School of Dentistry, Aracaju, SE, Brazil; 2. Universidade Federal de Sergipe - UFS, School of Dentistry, São Cristóvão, SE, Brazil; 3. Universidade Federal do Rio Grande do Norte - UFRN, School of Dentistry, Natal, RN, Brazil; 4. Institute for Technology and Research - ITP, Aracaju, SE, Brazil. ricardo.patologia@uol.com.br

\begin{abstract}
Spindle cell carcinoma (SpCC) is a rare biphasic tumor of epithelial origin that comprises squamous and sarcomatoid components. The diagnosis may be challenging, particularly when the squamous differentiation is not obvious. SpCC of the tongue has rarely been reported. Here we report a case of SpCC on the right border of the tongue of a 28-year-old male. The diagnosis was based on the correlation of clinical, morphological, and immunohistochemical findings. We describe this rare tumor, present at an unusual location in a young patient to contribute to better understanding and awareness of this rare malignancy.
\end{abstract}

KEYWORDS: Carcinoma. Spindle cell carcinoma. Differential diagnosis.

\section{INTRODUCTION}

Spindle cell carcinoma (SpCC) is a rare variant of squamous cell carcinoma (SCC) characterized by a biphasic morphological pattern, with superficial areas of conventional SCC and underlying areas of spindle-shaped neoplastic proliferation (THOMPSON, 2003). Since there are different possible interpretations for the sarcomatoid component (reactive vs. neoplastic and mesenchymal vs. epithelial), SpCC has received alternative names such as sarcomatoid carcinoma, pseudosarcoma, carcinosarcoma, and pleomorphic carcinoma.

SpCC accounts for approximately $3 \%$ of all SCCs of the head and neck region, and it is most commonly found in the upper aerodigestive tract, including the oral cavity, larynx, tonsils, and pharynx (VISWANATHAN et al., 2010). In oral sites, SpCC tends to appear as a painless exophytic polypoid lesion with an ulcerated surface, predominately in males in the fifth and sixth decades of life (ROMAÑACH et al., 2010). The buccal mucosa and tongue are most commonly affected (SARMA et al., 2012); however, cases of central SpCC occurring in the jaw bones have also been reported (RAVINDRAN et al., 2013; RATH et al., 2014). SpCC is an aggressive tumor with high local recurrence $(73.3 \%)$ and distant metastasis $(33.3 \%)$ rates, and an overall survival time of about 9 months (SU et al., 2006). In addition, SpCC is more likely to present nodal metastases at an early stage than conventional SCC (GERRY et al., 2014).

Because the behavior of SpCC seems to be more aggressive than that of SCC at a similar stage, requiring wider safety margins $(>2 \mathrm{~cm})$ during surgical intervention and chemotherapy protocol for the control of distant metastasis (SU et al., 2006), accurate diagnosis of $\mathrm{SpCC}$ has important implications for its management. However, this tumor has been regarded as a significant diagnostic challenge to the pathologist because of the remarkable overlap of its clinical, histopathological, and immunohistochemical features with those of malignant spindle cell tumors (PARIKH; DESAI, 2011).

As only some cases of intraoral SpCC have been described to date, we report a case of a SpCC occurring in a young patient, with the goal of contributing to better understanding and awareness of this rare malignancy.

\section{CASE REPORT}

A 28-year-old male patient was referred to the School of Dentistry because of a painless ulcerated lesion located in the tongue, with no history of previous trauma. The patient reported that the ulcer had grown considerably over the past six weeks. Clinical examination revealed a solitary ulceroproliferative lesion on the right lateral border of the tongue (Figure 1). The lesion was irregular in 
shape, had an ulcerated necrotic center and mildly polypoid margins, and measured approximately 3.0 $\times 4.0 \mathrm{~cm}$. The tumor was adherent to underlying structures, and there was no sign of regional lymphadenopathy. Clinical diagnosis of lingual SCC was made. An incisional biopsy was performed, and the sample was sent for histopathological analysis. Microscopic examination revealed a morphologically biphasic neoplasm that consisted of proliferating atypical nests of squamous epithelial cells on the surface and pleomorphic spindle cells, arranged in fascicles, forming the main bulk of the tumor. Proliferating capillaries and inflammatory cells were also observed adjacent to the surface ulceration (Figure 2). Immunohistochemical analysis revealed that tumor cells were positive for pancytokeratin, cytokeratin 14 (CK14), vimentin, alpha-smooth muscle actin ( $\alpha$-SMA), and Ki-67 but negative for S-100 and desmin (Figure 3). The final diagnosis was SCC. The patient was referred to the Head and Neck Oncology Center of the Urgency Hospital of Sergipe (Brazil) for further surgical and radiotherapeutic management.

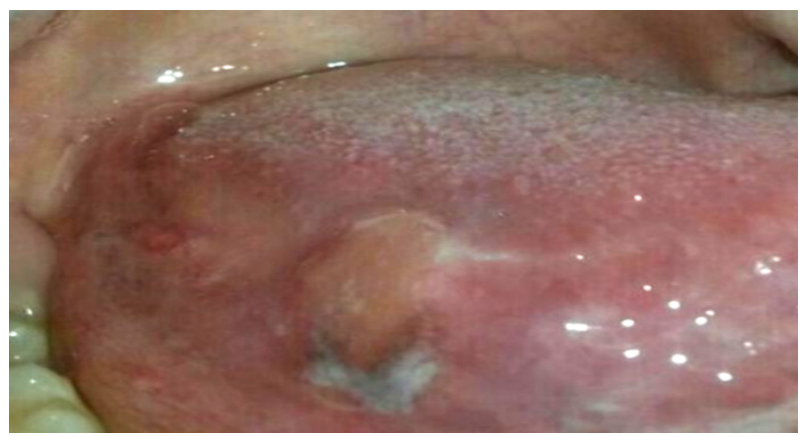

Figure 1. Solitary, painless irregular lesion with ulcerated necrotic center and mildly polypoid margins, located on the right lateral border of the tongue, and measuring approximately $3.0 \times 4.0 \mathrm{~cm}$.
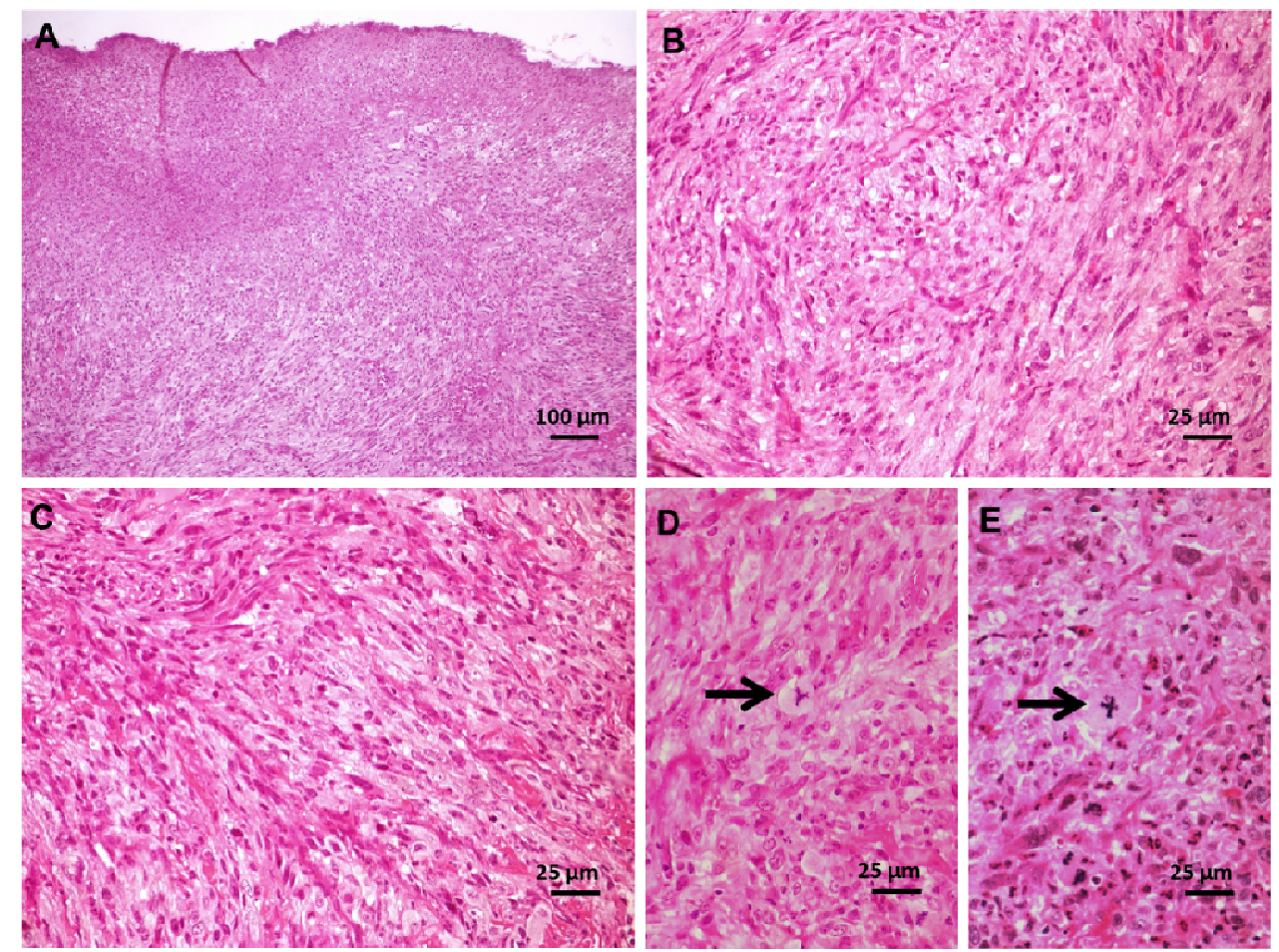

Figure 2. Pathological features of SCC. (A) Tumor cells proliferating within the connective tissue, under an ulcerated surface $(\mathrm{HE}, \times 100)$. (B) Atypical nests of squamous epithelial cells on the surface and (C) pleomorphic spindle cells arranged in fascicles at the bottom of the histological sample (HE, $\times 400)$. (D) Bizarre tripolar and (E) tetrapolar mitotic figures (arrows) were seen throughout the tumor parenchymal cells $(\mathrm{HE}, \times 400)$. 


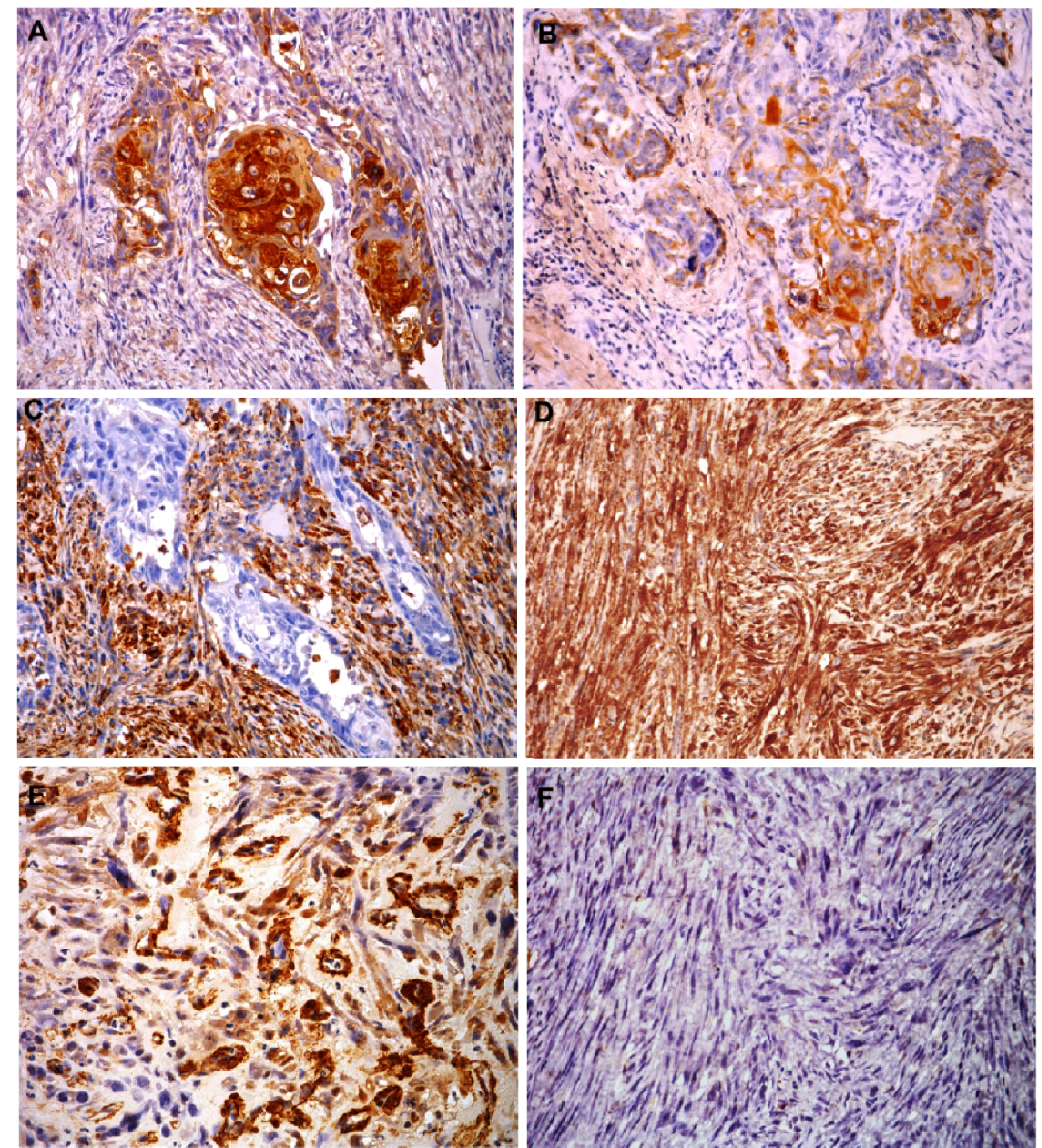

Figure 3. Immunohistochemical profile of SCC. (A) Squamous tumor cells showing intense positivity for pancytokeratin AE1/AE3 and (B) cytokeratin 14 (CK14). (C and D) Spindle tumor cells showing intense positivity for vimentin. (E) Positivity for $\alpha$-SMA was limited to the walls of capillary vessels but negative in tumor parenchymal cells. (F) Negativity for S-100 protein (LSAB, $\times 400$ ).

SpCC is a rare biphasic malignant neoplasm of the head and neck region that consists of sarcomatoid proliferation of pleomorphic spindleshaped cells in association with SCC (VISWANATHAN et al., 2010). These tumors are uncommon in the oral cavity, accounting for less than $1 \%$ of all tumors of the oral region (JORDAN; REGEZI, 2003). Clinicopathological studies have demonstrated that SpCC is more common in males than in females. It affects men in the age group of 40 to 60 years, and when located in the soft tissues of the oral cavity, the tongue, buccal mucosa, and alveolar/gingival mucosa are the most affected anatomical sites (TAKATA et al., 1991; ROMAÑACH et al., 2010). The age of our patient is 28 years, which is well under the typical age range described in the literature. In fact, longer series of
SpCC reported in the last five years have demonstrated that less than $6 \%$ of these rare tumors arise in patients between 20 and 30 years old (VISWANATHAN et al., 2010; SARMA et al., 2012), attesting the uniqueness of the current case. Although uncommon, the occurrence of this tumor in the tongue has been described in other reports of intraoral SpCC (CHEN et al., 1998; KOSEOGLU et al., 2005; OKTAY et al., 2011; BIRADAR et al., 2014). Potential risk factors include the history of tobacco use, alcohol abuse, poor oral hygiene, and previous radiotherapy (WENIG, 2002). However, none of these factors are applicable to the present case, suggesting that because of the multifactorial nature of carcinogenesis, other factors could be related to tumor emergence rather than the classic risk factors. 
The case reported here featured a typical polypoid growth with an ulcerated surface. Although the spindle cell components have been considered to be a variant growth pattern of SCC, a non-neoplastic mesenchymal reaction, or a malignant admixture of epithelial and mesenchymal neoplasms, the majority of sarcomatoid components are non-diploid, indicating that these cells are truly neoplastic in nature (SU et al., 2006). In addition, other evidence seems to support the hypothesis of an epithelial origin, with "de-differentiation" to a spindle cell morphology, such as: i) the occurrence in the exact sites that normally have the squamous epithelium; ii) preponderance of carcinomas rather than sarcomas; iii) direct continuity and smooth transition of spindle cells into areas of the squamous epithelium; and iv) dual expression of epithelial and mesenchymal antigens of differentiation in neoplastic spindle cells (SARMA et al., 2012). The mechanisms underlying spindle cell differentiation in SpCC remain unclear; however, a possible role played by the downregulation of cytoskeletal genes required for epithelial differentiation induced by the expression of the transcription factor Snail has been proposed to explain the typical "sarcomatoid dedifferentiation" in SpCC (KIM et al., 2009).

The diagnosis of this type of tumor can be challenging, particularly when the SCC component is not obvious. Thus, to establish a correct diagnosis, the presence of two distinct epithelialderived components needs to be assessed: (1) a carcinomatous component comprising a minor portion of the tumor mass, which may be represented by dysplasia, in situ carcinoma, or frankly invasive SCC; and (2) a pleomorphic storiform and/or fasciculated sarcomatous component, usually comprising the majority of the tumor (THOMPSON, 2003). In the present case, islands and nests of typical SCC and a "fibrosarcoma-like" proliferation of spindle cells were distinctive features of the tumor parenchyma, which is consistent with SpCC.

Immunohistochemistry can be useful to rule out the hypothesis that spindle cells and epithelial cells simultaneously arise from separate stem cells (representing a "collision" tumor) and ensure the epithelial derivation of SpCC. The squamous component is strongly positive for epithelial markers such as pancytokeratin (AE1/AE3) and
CK14, whereas the spindle cell component shows variable positivity, ranging from $40 \%$ to $85 \%$ of the cases (ROMAÑACH et al., 2010). On the other hand, the expression of mesenchymal markers in SpCC can be helpful to exclude other sarcomas of the oral cavity. Thus, the spindle cell component shows high positivity for vimentin and highly variable expression of $\alpha$-SMA, desmin, and S-100 protein, whereas the carcinomatous component shows negativity or only focal positivity for these markers (VISWANATHAN et al., 2010). In accordance with these accounts, the present case showed high positivity for AE1/AE3 and CK14 in the squamous component, whereas the sarcomatoid component had moderate expression of these markers, attesting the epithelial origin of the tumor. In addition, the diffuse positivity for vimentin in spindle-shaped cells but not in squamous cells was also expected, reflecting the immunohistochemical profile of SpCC. The lack of S-100 expression excludes a possible neural derivation of the spindle cells, whereas the positivity for $\alpha$-SMA, limited to the periphery of blood vessel walls but not to proliferative pleomorphic cells, suggests that only non-parenchymatous pericytes were labeled, excluding smooth muscle or myofibroblast differentiation.

Oral SpCCs are potentially aggressive and tend to show high recurrence and metastasis rates (PARIKH; DESAI, 2011). However, early-stage tumors usually have a better prognosis than deeply invasive tumors (SU et al., 2006). In the present case, although the tumor was extensive, no signs of clinical lymph node compromise were detected, which may represent good prognosis.

In summary, we have presented a rare case of SpCC of the tongue occurring in a young patient and discussed the clinicopathological and immunohistochemical parameters of diagnosis. Despite its challenging morphological appearance, the histopathological identification of a squamous cell component and determination of the epithelial nature of spindle cells are critical to guide the pathologist to an accurate diagnosis. Furthermore, considering the rarity of soft tissue sarcomas of the oral cavity (ALJABAB et al., 2011), SpCC should always be considered as a possible diagnosis of polypoid lesions of this region containing spindle cells. 
RESUMO: O carcinoma de células fusiformes (CCF) é um tumor bifásico raro de origem epitelial que compreende componentes escamosos e sarcomatoides. O diagnóstico pode ser desafiador, particularmente quando a diferenciação escamosa não é óbvia. Relatos de CCF em língua são extremamente raros. Aqui é relatado um caso de CCF na borda direita da língua de um homem de 28 anos de idade. O diagnóstico foi baseado na correlação de achados clínicos, morfológicos e imunohistoquímicos. Com a descrição deste caso clínico, em uma localização anatômica incomum e em um paciente jovem, pretende-se contribuir para uma melhor compreensão e conhecimento deste tumor maligno raro.

PALAVRAS CHAVE: Carcinoma. Carcinoma epidermoide. Diagnóstico diferencial.

\section{REFERENCES}

ALJABAB, A. S.; NASON, R. W.; KAZI, R.; PATHAK; K. A. Head and neck soft tissue sarcoma. Indian J Surg Oncol, Winnipeg, v. 2, p. 286-290, Dec. 2011. https://doi.org/10.1007/s13193-012-0127-5

BIRADAR, M. V.; DANTKALE, S. S.; ABHANGE, R. S.; KAMRA, H. T.; BIRLA, K. Spindle cell carcinoma of the tongue: a rare variant of squamous cell carcinoma. Ecancermedicalscience, Latur, v. 8, p. 1-7, Jul. 2014.

CHEN, Y. K.; LIN, C. C.; CHEN, C. H.; YAN, Y. H.; LIN, L. M. Spindle cell carcinoma of the tongue: case report and immunohistochemical study. Oral Med Pathol, Kaohiung, v. 3, p. 51-54, 1998.

GERRY, D.; FRITSCH, V. A.; LENTSCH, E. J. Spindle cell carcinoma of the upper aerodigestive tract: an analysis of 341 cases with comparison to conventional squamous cell carcinoma. Ann Otol Rhinol Laryngol, Charleston, v. 123, p. 576-583, Aug. 2014. https://doi.org/10.1177/0003489414525337

JORDAN, R. C.; REGEZI, J. A. Oral spindle cell neoplasm: A review of 307 cases. Oral Surg Oral Med Oral Pathol Oral Radiol Endod, California, v. 95, p. 717-724, Jun. 2003. https://doi.org/10.1067/moe.2003.1400

KIM, E. J.; CHE, Z. M.; PARK, Y. J.; HWANG, Y. S.; KIM, K. Y.; JUNG, D. W.; JEON, N. K.; CHOI, Y. W.; LEE, E. J.; KIM, J. Morphogenesis and biological significance of spindle cell transformation in a spindle cell carcinoma. Cancer Lett, Seoul, v. 275, p. 61-71, Mar. 2009. https://doi.org/10.1016/j.canlet.2008.10.004

KOSEOGLU, R. D.; SERTCELIK, A.; AYVA, Y. A rare variant of squamous cell carcinoma of the tongue; spindle cell carcinoma. J Ankara Univ Facul Med, Tokat, v. 58, p. 11-14, May. 2005.

OKTAY, M.; KOKENEK-UNAL, T. D.; OCAL, B.; SAYLAM, G.; KORKMAZ, M. H.; ALPER, M. Spindle cell carcinoma of the tongue: a rare tumor in an unusual location. Patholog Res Int, Ankara, v. 2011, p. 1-6, Jan. 2011. https://doi.org/10.4061/2011/572381

PARIKH, N.; DESAI, N. Spindle Cell Carcinoma of the oral cavity: A case report of a rare entity and review of literature. J Academy Adv Dental Research, Gandhinagar, v. 2, p. 31-36, Apr. 2011.

RATH, R.; DAS, B. K.; DAS, S.; BAISAKH, M. Spindle cell carcinoma of maxilla: Histomorphological and immunohistochemical analysis of a case. J Oral Maxillofac Pathol, Odisha, v. 18: p. 256-261, May-Aug. 2014.

RAVIDRAN, R.; MOHAN, V.; SAJI, A. M. Spindle cell carcinoma of maxilla: case report of a rare entity and review of literature. Oral Maxillofac Pathol J, Kerala, v. 4, p. 379-384, July-Dec. 2013.

ROMAÑACH, M. J.; AZEVEDO, R. S.; CARLOS, R.; ALMEIDA, O. P.; PIRES, F. R. Clinicopathological and immunohistochemical features of oral spindle cell carcinoma. J Oral Pathol Med, Piracicaba, v. 39, p. 335-341, Apr. 2010. https://doi.org/10.1111/j.1600-0714.2009.00843.x 
SARMA, A.; DAS, R.; SHARMA, J. D.; KATAKI, A. C. Spindle cell carcinoma of the head and neck: a clinicopathological and immunohistochemical study of 40 cases. J Cancer Ther, Guwahati, v. 3, p. 1055-1059, Dec. 2012. https://doi.org/10.4236/jct.2012.36137

SU, H.; CHU, S.; HOU, Y.; CHANG, K.; CHEN, C. Spindle cell carcinoma of the oral cavity and oropharynx: factors affecting outcome. J Chin Med Assoc, Kaohsiung, v. 69, p. 478-483, Oct. 2006. https://doi.org/10.1016/S1726-4901(09)70312-0

TAKATA, T.; ITO, H.; OGAWA, I.; MIYAUCHI, M.; IJUHIN, N.; NIKAI, H. Spindle cell squamous carcinoma of the oral region. Virchows Archiv A Pathol Anat, Hiroshima, v. 419, p. 177-182, May. 1991.

THOMPSON, L. D. R. Squamous cell carcinoma variants of the head and neck. Curr Diagn Pathol, Woodland Hill, v. 9, p. 384-396, Dec. 2003.

VISWANATHAN, S.; RAHMAN, K.; PALLAVI, S.; SACHIN, J.; PATIL, A.; CHATURVEDI, P.; D'CRUZ, A.; AGARWAL, J.; KANE, S. V. Sarcomatoid (spindle cell) carcinoma of the head and neck mucosal region: a clinicopathologic review of 103 cases from a tertiary referral cancer centre. Head Neck Pathol, Mumbai, v. 4, p. 265-275, Dec. 2010. https://doi.org/10.1007/s12105-010-0204-4

WENIG, B. M. Squamous cell carcinoma of the upper aerodigestive tract: precursors and problematic variants.

Mod Pathol, New York, v. 15, p. 229-254, Mar. 2002. https://doi.org/10.1038/modpathol.3880520 